\title{
Leisure Time Management: A New Approach toward Employees Loyalty
}

\author{
Gholam Ali Tabarsa ${ }^{1}$, Maryam Tehrani ${ }^{1}$, Nima Lotfi ${ }^{1}$, Mona Ahadian $^{1}$, Azadeh Baniasadi $^{1}$ \& Elaheh Tabarsa ${ }^{1}$ \\ ${ }^{1}$ Faculty of Management and Accounting, Shahid Beheshti University, Tehran, Iran \\ Correspondence: Maryam Tehrani, PhD Student, Faculty of Management and Accounting, Shahid Beheshti \\ University, Tehran, Iran. E-mail: mtehrani_mt@yahoo.com
}

Received: January 27, 2013

Accepted: July 17, 2013

Online Published: August 1, 2013

doi:10.5430/jms.v4n3p65

URL: http://dx.doi.org/10.5430/jms.v4n3p65

\begin{abstract}
This study deals with clarifying the effect of leisure time management on employees' loyalty and to develop a Structural Equation Model (SEM) for leisure time management vs. employee loyalty. Therefore the study addresses the main components involving in leisure time management, organizational loyalty, perceived management concern for employees, work-family balance and work-role salience based on the results of the literature review and conducting a new conceptual model. To test the model a total of 248 employees from the Iranian oil Industry were asked as the research participants and the five dimensions of the conceptual model were measured among them. The structural equation model of the research showed that leisure time management has positive effects on employees' work-role salience and their perception of management concern for employees, while these two later variables have positive effects on employees' work-role salience. The result also showed that employees' work-role salience has a positive effect on their organizational loyalty. Therefore, it was revealed that within the organizational context, management concerns for planning and suggesting optional leisure activities to their employees can indirectly improve employees' organizational loyalty through increasing the mediating role of employees' work-family balance, perceived management concerns for employees and work-role salience.
\end{abstract}

Keywords: leisure time management, work-family balance, perceived management concern for employees, work-role salience, employee loyalty

\section{Introduction}

In today's organizations, human abilities are considered as the most critical and strategic resources in achieving organizational goals and missions due to the change of the environmental contingencies in ways that have caused the role of human resources in organizational success much more important than physical resources. Therefore, effective human resource management is of critical importance in order to fulfill employees' different financial and psychological needs and motivating them toward organizational goals. Since money can only fulfill the primary needs of human being, obviously, it is not only the case of money that can satisfy employees and guarantees their full motivation in their works. It means that employees' psychological needs in a long period of time have much more influential role in increasing their motivation, and human resource managers' attention to the ways that their employees like to spend their leisure times makes a framework for providing voluntary, recreational leisure programs, such as celebrations, travels, athletic activities, etc. Such activities have potential to increase employees' leisure time satisfaction and psychological health. It is also important to notice that within the organizational context, providing any optional leisure programs to help employees enjoy their nonworking times demands a set of complementary functions and commitment of all the human resource managers.

Leisure time management is a new concept in the field of human resource management and although some researchers have found that leisure activities are related to work specific outcomes such as higher job satisfaction (Parks and Steelman, 2008), productivity at work (Briazgounov, 1988), fewer days off from work (Parks and Steelman, 2008), enthusiasm at work (Thørgersen-Ntoumani et al., 2005), and contributes to lower health care costs (Briazgounov, 1988), till now no studies have explicitly referred to all the integrated steps of leisure time management process as a function of human resource management unit and also there are not any empirical research findings in the organizational domain to show the effects of leisure time management on employees' personal feelings and moods. 
Therefore the main purpose of the current study is to introduce for the first time the concept of leisure time management into the literature of human resource management. This study is also subjected to examine appropriate personal and organizational outcomes that are provided by an organization's voluntary leisure programs in the frame of leisure time management.

\subsection{Leisure Time Management}

Leisure studies emerge from a different set of traditions. First and foremost, it was concerned with the social problem of the use of free time in industrial societies, where the portion of life devoted to work was being constantly reduced. Leisure studies was grounded first in sociology; studies of everyday life, time use, suburbanization and primarily of work. The first sociologists of leisure initially focused on industrial work. As industrial sociologists began following workers home (primarily males) and to see what the rest of life was like, the sociology of leisure was born, by accident (Godbey, 2000). Most definitions of a holiday view it as a break from work or studies (Cambridge International Dictionary, Collins English Dictionary, 1998) and consider holidays as leisure time. However neither time off work (e.g. weekends, evenings), nor holidays necessarily represent a break from work (Foley and McGillivray, 2000).

The concept of time can be categorized as following:

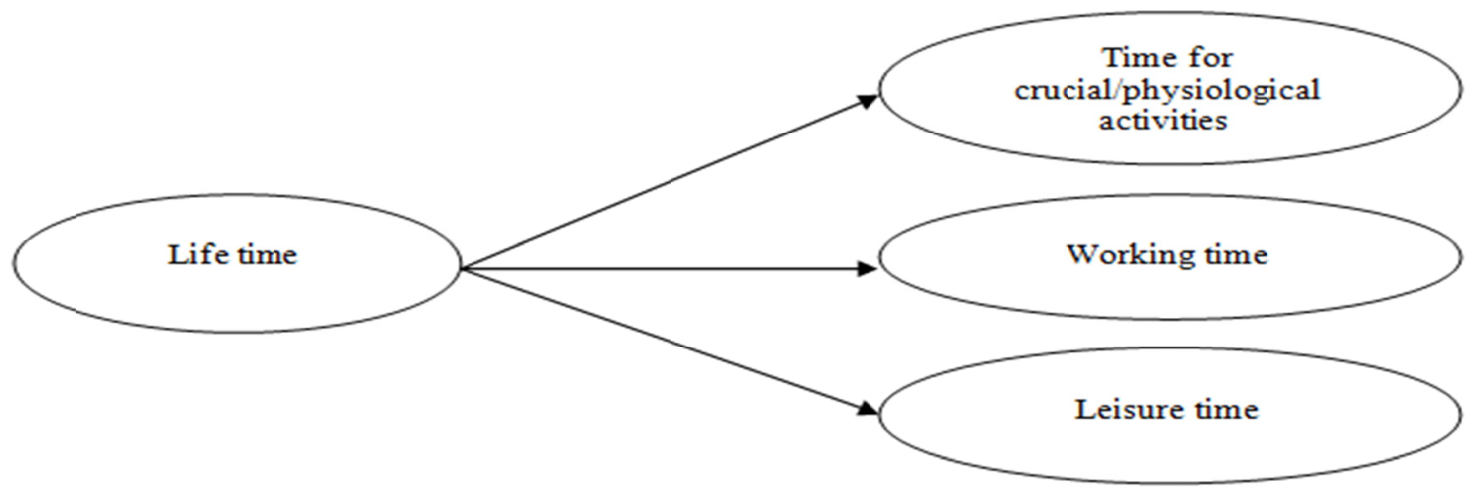

Figure 1. Time categorization

- Time for physiological activities: Fulfilling those activities which are critical to be alive, such as eating, sleeping, etc.

- Working time: The amount of time that is allocated for doing formal job activities. These activities have economic values.

- Leisure time: Periods of time that people far from their job responsibilities and any kind of formal organizational tasks are involved in special kinds of activities that necessarily do not have economic value and based on their amusing, recreating essence can improve people's internal calmness.

Therefore, Leisure has at least three distinct meanings. The first use of the word "leisure" is as a residual time concept, usually taken to mean "time off" after routine work place and domestic chores, together with other unavoidable obligations such as personal hygiene or commuting, have been completed. The second use of the term is as a generic descriptor to indicate certain activities which, broadly, function to re-create individuals or groups. Most commonly, this use of "leisure" is associated with the idea of recreations. Third, leisure is perceived as a state of mind whereby individuals feel that they are "at leisure" in any particular set of circumstances. (Foley et al, 1999).

Although examples of employer-sponsored leisure provisions were visible as early as the 17th century (see Burton, 1994; Campbell, 1979), the most important employer interventions in the leisure lives of employees have been associated with industrial capitalism. In the 19th century, paternalistic, enlightened industrialists consistently provided leisure opportunities connected to the workplace. The early 1980s saw a major increase in the number of organizations providing wellness programs concentrated on the modification of employee lifestyle behavior (Chu et al., 2000). Reviewing the literature revealed that most of the academic works around leisure management consider this phenomenon as a new concept of urban life (Touve and Tepper, 2007) and some another as a new field of 
studies in educational institutes(Pitchford and Bacon William, 2005) and although some scholars approach it as a new task in organizations (Savinainen et al., 2005) the exact meaning of the concept has not clarified in the related books and articles. Leisure time management is about planning, organizing and resourcing appropriate facilities to provide voluntary leisure and recreation programs for employees' non-working time, implementing the programs and evaluating the proper results of the programs.

Based on a systematic approach, leisure time management is consisted of 5 main phases that are interrelated and complementary:

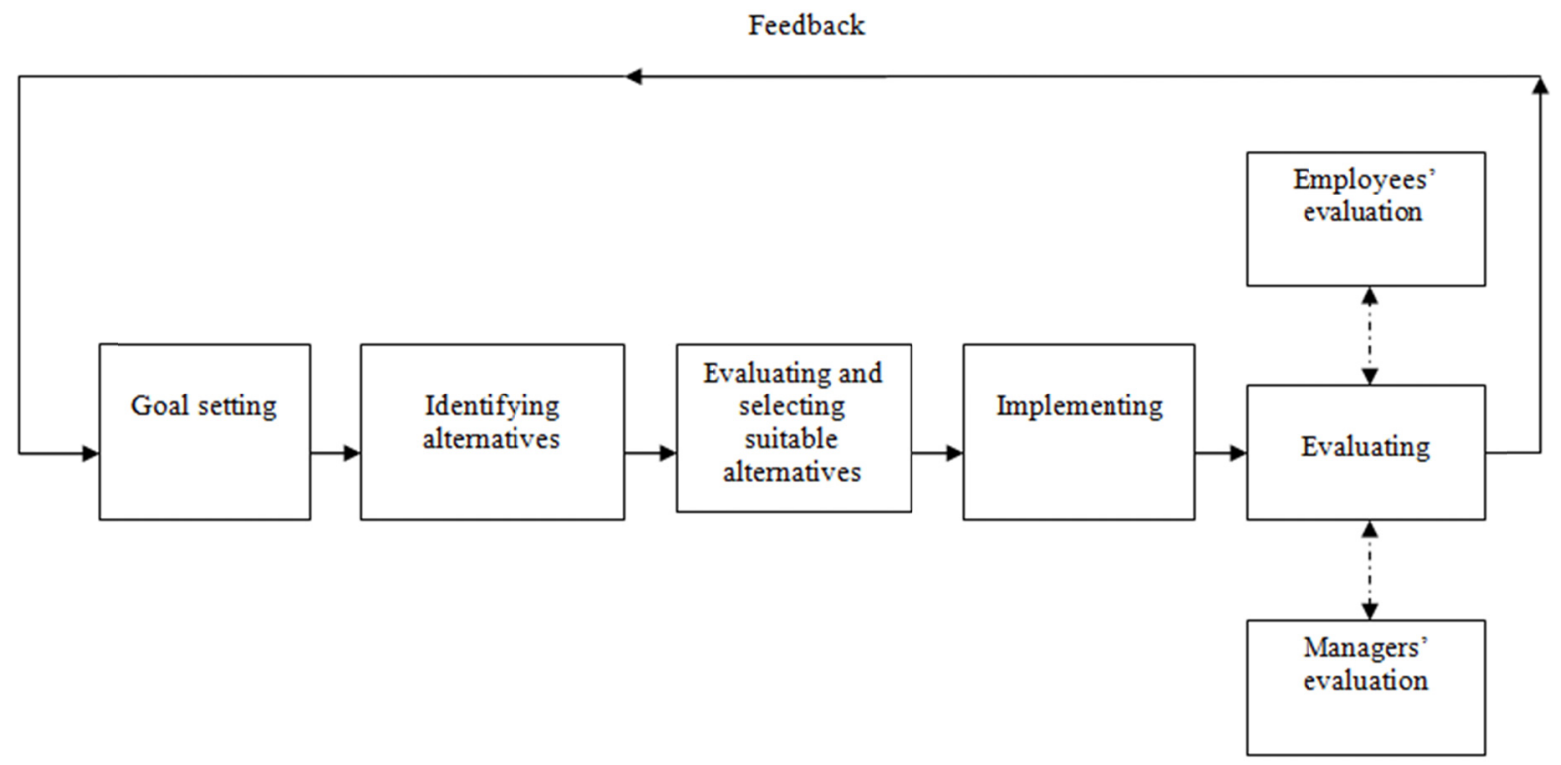

Figure 2. Leisure time management process

Phases 1: Leisure time management goal setting

The goal of leisure time management is a combination of managers' goals of providing voluntary recreational programs and employees' goals of attending in such programs. Some of the goals that are set in this phase are as following:

- Improving employees' psychological health (reinforcing and decreasing the level of stress).

- Growth of creativity

- Human resource development

Phases 2: Identifying different alternatives as leisure programs

In this phase managers and planners of an organization should try to identify different alternative programs that can be provided and suggested by the organization as recreating, pleasure activities during their employees' leisure time (activities such as group hiking, mounting, athletic teams, attending various celebrities, family travels and other programs that all of them are provided by the organization for its employees and their families). One of the most important points in this phase is that those activities that are identified as free time activities must be clearly distinguishable from formal job activities in organizations.

Organizations must avoid delivering only what the users of their leisure programs ask and expect of them. Instead they must act on their potential to excite, delight, and bring surprising pleasures. The key is uncovering unexpected needs and desires and acting on innovations that cause leisure programs' users' excitement (Erdly et al., 2003).

\section{Phases 3: evaluating and suggesting suitable leisure programs}

There are special contingencies, necessities and limitations related to leisure activities that an organization might face with, therefore these factors can be categorized into 2 groups and must be considered as criteria for evaluating and selecting appropriate leisure programs:

- Organizational factors: there are different organizational factors that must be considered by human resource managers when they intend to evaluate and select a number of voluntary programs for their 
employees' leisure time. Organizational goals and resources are 2 of the most important factors that affect whole the process of leisure time management.

- Employees' factors: several researches revealed that employees' characteristics is an important and influential factors in forming their desires during leisure time (Barnett, 2006). Time style is a relatively enduring aspect of the self, changeable only over a fairly long period of time. Further, Leisure behaviors and consumption patterns can be explained, at least in part, by people's time style. Four dimensions of time style appears to be particularly relevant to leisure program providers (Cotte, 2003):

1). Social orientation: this dimension refers to the categorization of discretionary time as either time for self or time with/for others (Hall, 1976; Manrai and Manrai, 1995; Rhee et al., 1995). The motivation to classify a unit of time as time for others can be either voluntary or obligatory (Cotte, 2003).

2). Temporal orientation: the relative significance individuals attach to the past, present or the future (Cotte, 1976; Holbrook, 1993; Holman, 1981; Jones, 1988; Philipp, 1992). It indicates whether people prefer to look back at events and accomplishments, live in the here and now, or look forward to whether may unfold.

3). Planning orientation: the style of time management. It involves a continuum from analytic (people who plan very extensively) to spontaneous (people who prefer not to plan at all) (Cotte, 2003).

4). Polychronic orientation: preference for polychronic, multi-tasking style versus a monochronic, "one-thing-at-a-time" style (Kaufman et al., 1991).

Some other scholars refer to factors such as motivational tendencies (Barnett, 2006), cultural values (Cotte, 2003) and gender and age (Bromley, 2005; Sivan, 2000) as personal factors affecting employees' tendencies toward different activities during their leisure time.

At the end of this phase, suitable recreational programs are suggested to employees and they can vulnerably choose the programs on the basis of their interests and needs. Some time recreational programs in organizations are designed in ways that it is possible for employees to attend the programs with their family members.

\section{Phases 4: implementing selected leisure programs}

In this phase of the leisure time management process, the selected leisure programs should be implemented in effective ways. There are two general ways for implementing leisure programs: in the first way, the organization provides and implement the voluntary leisure programs itself, that it requires preparing all the necessary equipments, human resources and facilities for the leisure activities implementation by a responsible department within the organization. Based on the second way, a contractor implements the leisure programs on behalf of the organization for its employees. Finally what is important is the concern of this phase about the qualitative and effective implementation of the voluntary recreational programs.

Phases 5: evaluating the implemented programs

In the last phase of the leisure time management two groups of information should be evaluated: The first group refers to the management evaluations of the implemented programs and the intended results. The second group of information is about employees' evaluations of the programs. Finally, based on the evaluation results, improvements occur in different phases of leisure time management process.

\subsection{Work- Family Balance}

Work-family research has tended to focus on relationships between specific work and family variables and usually from either a family-focused or a work-focused perspective (Heraty et al., 2008) and Researchers interested in the interface between work and family roles have identified two broad types of interdependencies, one negative and the other positive (Powell and Greenhaus, 2006). Till now, most of the literature has considered the negative side of the work-family (WF) interface, which is about WF conflict. According to the role theory (Katz and Kahn, 1966, cited in Beham and Drobnic, 2010), negative work-home interference or work-family conflict is defined as "a type of inter-role conflict that occurs when the role demands stemming from one domain (work or family) interfere or are incompatible with role demands stemming from the other domain (family or work)" (Beham and Drobnic, 2010). Three different forms of conflict are as following (Burke and El-Kot, 2010):

- Time-based - the time devoted to one role makes it more difficult to participate successfully in the other role.

- Strain-based - strains in one role make it more difficult to participate or be successful in the other role. 
- Behavior-based - behaviors expected or required in one role are incompatible with behaviors required or expected in the other role.

Since empirical studies have revealed a number of negative consequences of high levels of work-to-family conflict for individuals, such as turnover, burnout, life stress and strain (Allen et al., 2000), how to balance work and family demands and achieve a satisfactory equilibrium between the two realms has become a central question for organizations and an important career value for many employees (Valcour, 2007). Work-life balance (WLB) is defined as the extent to which an individual is "equally engaged in - and equally satisfied with" his or her work and non-work roles (Turner et al., 2009). Work-family balance is composed of a lack of conflict between work and family domains, as well as the positive spillover between the two sets of responsibilities (Marcinkus et al., 2007) that has implications for employee attitudes, behaviors, wellbeing as well as organizational effectiveness (Eby et al., 2005; Baral and Bhargava, 2010). The extant literature on the subject of work-life balance tends to make three assumptions (Moore, 2007):

(1) that workers are worse off than management when it comes to work-life balance issues;

(2) that improving a company's employees' work-life balance leads not only to greater productivity but to greater company loyalty and job satisfaction; and

(3) that work-life balance can best be maintained by programs and initiatives taking advantage of flexible working practices.

Therefore, due to the direct effects of family life on working life and vice versa, Warren and Johnson (1995) identified three types of work resources aimed at promoting work-family balance: family-oriented benefits, family-friendly organization culture, and supportive supervisor practices (Lu et al., 2009).

Finally, Work-life balance has implications for employee attitudes, behaviors, wellbeing as well as organizational effectiveness (Eby et al., 2005). As proposed by Greenhaus and Powell (2006) five types of resources may be generated in either role that influence the quality of life in the other role:

1. Skills and perspectives (e.g. cognitive, interpersonal, and multi-tasking skills; ways of defining problems or situations);

2. Psychological and physical resources (e.g. self-esteem, optimism, physical health);

3. Social-capital resources (i.e. influence and information derived from interpersonal relationships in work and family roles);

4. Flexibility (i.e. discretion in the timing, pace, and location at which role requirements are met); and

5. Material resources (i.e. money and gifts derived from the work or family domains).

\subsection{Perceived Management Concern for Employees}

The terms perceived management concern for employees was first introduced by Burke et al. (1992) to label a critical dimension of psychological climate. Under their conceptualization, the management concern -for-employees dimension refers to frontline employees' cognitive appraisals of management behaviors and actions (e.g., teamwork, rewards and recognition, listening to employees, eliminating fear or intimidation, degree of "walking the talk") as they relate to their own well-being. Such cognitive evaluations by employees are manifestations of the management concern -for-employees' dimension of psychological climate. The concept of management concern for employees is also known as labor-friendly practices. These practices are potential means of fostering shareholder value maximization. Labor-friendly programs can also be defined as those that treat employees as special stakeholders by devoting significant resources (financial and otherwise) to enhancing their welfare and helping them balance their home and work lives (Faleye and Trahan, 2007). The basic argument in favor of these programs is their potential to stimulate workforce loyalty and foster lower absenteeism, reduced turnover and better productivity (Faleye and Trahan, 2010).

Relying on social exchange theory, Whitener (2001) show that employees' perception of their organization's commitment to them as demonstrated by positive beneficial actions strongly influences the level of their commitment to the firm and its goals. Buck (2010) considers an expressed management concern for employees' learning, growth, and development and their opportunities for advancement and promotion, and a commitment to fair decisions about advancement and promotion as a component of its engagement model. In other words if employees feel that they are as an important management concern for their organization, they will have more tendency to participate in organizational processes. 


\subsection{Work-Role Salience}

Roles provide individuals with a framework on which to develop a sense of meaning, purpose, and agency (Reitzes and Mutran, 1994). Roles are attached to statuses, which Merton (1957) defined as positions in society. An individual occupying a status plays a number of roles associated with it. Accompanying the status is identity, the meaning that one attributes to himself or herself by virtue of occupying a particular role in a social structure that he or she subsequently views as descriptive of oneself (Thoits, 1995). Because one has many roles, he or she also has multiple identities. However, these identities are not equally salient to oneself (Noor, 2004).

Individuals vary on the importance they ascribe to life roles, such as their work or their family. This importance is referred to as role salience, and it influences one's beliefs about the personal relevance of a role, the standards of performance within that role, and the manner in which personal resources (e.g., time, money, energy) are devoted to that role (Amatea et al., 1986). Greenhaus was one of the first people to research and define the concepts of career salience and career commitment, which according to him, were both identified as the "perceived importance of work and a career in one's total life" (Greenhaus, 1971). In other words work-role salience is defined as the extent to which individuals' psychologically identify with the role of work (Pisarik, 2006). Role salience or importance-also known as role centrality (Martire and Townsend, 2000), role commitment (Brown et al., 1987), and personal involvement (Frone, Russell, and Cooper, 1995) - is said to provide individuals with meaning, self-worth, and purpose. As such, it should contribute positively to psychological well-being. Individuals who perceive work as highly salient are those people who psychologically identify with the role of work, look to work as a source of purpose and meaning, and rely on work to contribute significantly to their sense of self (Noor, 2004). The incorporation of role salience into the work-family literature is essential because role value and salience is central to organizing meaning and action for working people (Carlson and Kacmar, 2000). Greenhaus (1971) clarified career salience and argued that it consisted of three dimensions, all of which refer to specific items in the scale. 1) Relative importance of work and a career; 2) General attitude toward work and 3) Concern for planning and advancement. Amarea (1986) stated that high role salience is marked by placing a high value on the role (i.e., the extent to which the role is an important means of one's self-definition and/or their personal satisfaction) and high levels of commitment devoted to the role (i.e., the extent to which a person willingly commits personal resources to perform successfully in that role), that in organizational domain it refers to the concept of work-role salience.

\subsection{Employee Loyalty}

Employee loyalty is an important concept which has largely been ignored in neo-classical economics (Arai, 1995). It has its origins in studies of organizational commitment, behavioral intentions towards the organization, employee turnover behavior and organizational citizenship behavior. The key element of the employee loyalty construct, organizational commitment comes largely from the organizational behavior and applied psychology literature (Peloso, 2004).

Employee loyalty is an organizational citizenship behavior that reflects allegiance to the organization through the promotion of its interest and image to outsiders (Bettencourt et al., 2001). The concept is based on discrimination between a "we" and a "they". Identification with the "we", which may be a family, a company, a city, a nation or a local baseball team, allows individuals to experience satisfaction (gain utility) from success of the unit thus selected (Arai, 1995). Employees who engage in these loyalty behaviors act as advocators to outsiders of the organization's product, services and image (Peloso, 2004).Organizational loyalty as an allegiance to a concept outside the self has two components: an emotional/affective component and a goal allegiance component. The emotional/affective component mirrors the affective component of Meyer and Allen (1997): it involves workers' identification with, and emotional attachment to, their workplaces. The goal allegiance component addresses the loyalty employees feel toward an organization when that organization exemplifies or agrees with their own broader goals; this is similar to Meyer and Allen (1997)'s normative commitment. An example of this would be the worker who feels strongly about the environment and recycling; he is committed to his recycling job because it's in accordance with his goal to help the environment (Hoffmann, 2006). Chen, Tsui and Farh (2002) and Coughlan (2005) examined research that indicated, "Loyalty has sometime been used as a synonym for one or more forms of commitment". Organizational commitment means "remaining with one's firm". This form of commitment is frequently labeled "'loyalty' by organizational scholars" (Coughlan, 2005).

1995). Therefore, A loyal employee (Martensen and Grønholdt, 2006):

- is less likely to look for work elsewhere - expects to stay with the company both in the short- and long-term, 
- would recommend working for the company to others - proud to be working for the

- company,

- is interested in doing her/his best, and make an extra effort when required - this relates to the individual employee's performance and contribution to the company value,

- develops strong relations to the company - temporary dissatisfaction with the job is accepted,

- is interested in improving her/his own performance - offers suggestions for improvement,

- interested in participating in various training and educational activities, etc.,

- has an attitude and behavior that match the company's values, visions and goals.

According to Reichheld (2001) employees' organizational loyalty consists of 2 dimensions as 1) feeling about the organization (i.e., the extent to which an employee serve with honor as a member of the organization) and 2) relationship with the organization (i.e., the extent to which an employee think about a positive and strong relationship with his/her organization for a long time.

\subsection{Leisure Time Management and Work-Family Balance}

Research in work and organizational psychology has been particularly interested in studying the potential repercussions of work on other life domains. Workers who devote lots of time and energy towards their job sometime have difficulties to manage and/or balance the demands of work and family domains and have fewer resources for leisure activities, such as physical activity (Caudroit, 2011). Anecdotal evidence have shown that employees want to work for companies that recognize the importance of home, family, and personal time because the difficulties of balancing work and family responsibilities often result in increased work stress (Gutek et al., 1988).

Higgins et al. (1992) and Frone et al. (1992) confirm that work-family conflicts mainly result from the pressures and role expectations of work and family. In studying married workers, Frone et al. (1992) found that the pressure of job roles is related to work-family conflict. Such pressure may be reduced through social support. Dunseath et al. (1995) argued that workplace support reduced job pressure more than other types of support. Growing awareness of these issues - whether articulated as work-family or work and personal life - heralded the development of what became known initially as family friendly nonworking policies or more recently optional leisure programs provided by organizations to enrich employees' nonworking time. In summary, extant research show that employee services enhance employee retention as employees improve the balance and integration between work and family responsibilities (Thompson et al., 2004). Therefore, we hypothesize that organization' investment to provide leisure activities for employees increase the level of employees' work-family balance:

H1: Leisure time management in organization has a positive meaningful effect on employees' work-family balance.

\subsection{Leisure Time Management and Perceived Management Concern for Employees}

In line with Forrester's (2000) argument that management desires and good intentions do not mean much unless employees perceive them as such, management concern for employees should only be considered from employees' perspective. Specifically, we adopt Burke, Borucki, and Hurley's (1992) conceptualization and define this psychological climate construct as 'employees' cognitive appraisals of the managerial actions to enhance the well-being of their employees (Alexandrov et al., 2007). One of the important management actions to improve employees' well-being is about the various recreation programs that are provided for employees' leisure time. Therefore we constructed the second hypothesis as following:

H2: Leisure time management in organization has a positive meaningful effect on perceived management concern for employees.

\subsection{Work-Family Balance and Work-Role Salience}

Ashforth et al.'s (2000) boundary theory and Clark's (2000) work/family border theory argue that individuals cross permeable borders or boundaries between work and home life realms to create work-life balance and reduce role conflict. Having work-life balance can be described by "satisfaction and good functioning" in work, home, and leisure life realms (Clark, 2000). Border theory (Clark, 2000) provides a useful framework to develop our hypotheses. This theory proposes that each person's role takes place in different domains that are separated by physical, temporary, or psychological borders, although it is possible to 'cross borders' between domains, and people may differ in the way in which they cross these borders. Therefore, there are different types of border-crossers depending on the degree to which they are peripheral or central participants in either domain. Whereas peripheral border-crossers do not internalize the domain characteristics, central border-crossers identify personally with them. 
Specifically, border-crossers who are central participants in one domain feel more motivated to guard the borders of that domain (Clark, 2000). In this study, it means that individuals who are central border-crossers in the work domain are better able to balance their work and family issues and therefore, feel motivated and do not let family issues interfere with job tasks, in order to control what they do and to perform better and have work-role salience during their working time.

However, when the work domain is not central to the individual, it is easier to cross the border and start thinking about family-related issues at work (Clark, 2000). The third hypothesis of the study was constructed to explore the effect of work-family balance on employees' work-role salience:

H3: Work- family balance has a positive meaningful effect on employees' work- role salience.

\subsection{Perceived Management Concern for Employees and Work-Role Salience}

According to Eisenberger, Fasolo and Davis-LaMastro (1990), employees who feel supported by their managers and care about the organization would engage in activities that help to further the organization's goals. High levels of perceived organizational support creates feelings of obligation, to the employers as well as makes them feel they have to return the employers' commitment by engaging in behaviors that support organizational goals. From the social exchange perspective, research has revealed that perceived management/ organizational support is positively related to job attendance and measures of job performance (Eisenberger et al., 1986). In this research it is assumed that work-role salience is a feeling that may arises from employees' evaluation of how their managers and organizational policies concern about them and can directly affects their job performance. This is the basis of the forth hypothesis:

H4: Perceived management concern for employee has a positive meaningful effect on employees' work-role salience.

\subsection{Work-Role Salience and Employee Loyalty}

According to Greenhaus (1973) individuals high in work salience are more likely to seek out favorable working environments because they place greater emphasis on the importance of this. Therefore it can result in higher level of organizational commitment and after a period of time it will be developed to organizational loyalty. In addition what has not been mainly considered in the literature is the effect of work-role salience on work related attitudes. Regarding the main effects, Sanz-Vergel et al. (2011) found that trait work-role salience may be beneficial for daily work performance. Therefore, based on the related literature, work-role salience can result in high level of performance and organizational commitment and if we accept that within the employee-organization relationship employees' organizational loyalty is the next step after a high level of organizational commitment, we can represent the next hypothesis as following:

H5: Work-role salience has a positive meaningful effect on employees' loyalty.

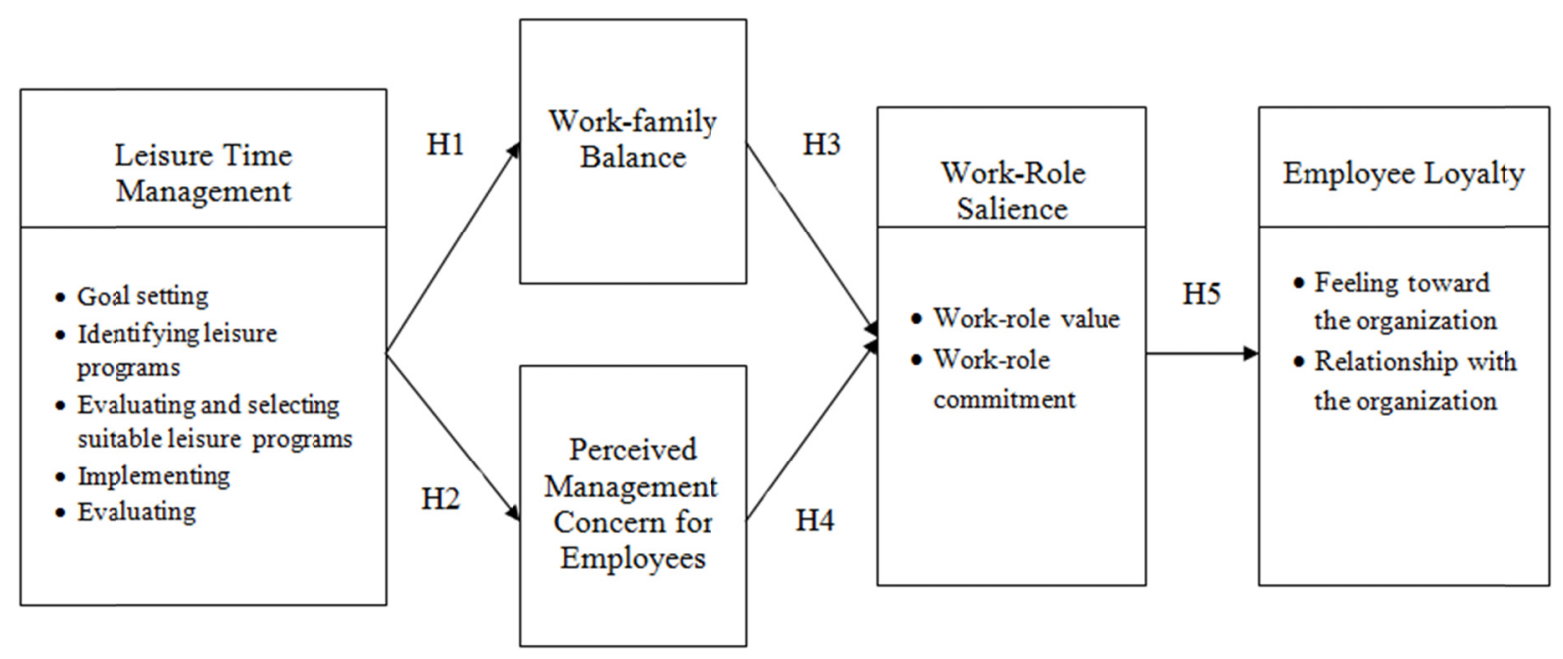

Figure 3. Research conceptual model 


\section{Method}

\subsection{Participants}

To test the hypothesis authors conducted their work among the employees of the Iranian National oil industry. A total of 320 questionnaires were distributed among the employees and 248 questionnaires were returned for a response rate of 77 percent. Of the participants 50 percent were male and 49 percents were female. About 38 percent of the employees were between the ages of 20 and 30,36 percent were aged 31 to 40 and 18 percent were between the age of 41 to 50 and a small proportion (6 percent) was over 51 years old. The majority of the sample had been working at the organization for four to ten years (50 percent); 31 percent between eleven to twenty years and 18 percent of the employees had been working at the organization for more than twenty one years.

\subsection{Measures}

Data collection was conducted by using 5 questionnaires:

Leisure time management. Authors conducted a 25 scales questionnaire to test the effectiveness of each of the five phases of leisure time management as a function of human resource management. All items had strong face validity. The scale also demonstrated high internal reliability (alpha $=0.98)$.

Employee loyalty. Reichheld (2001) instrument was used to measure employee loyalty in the current study. This instrument consisted of two sets of questions. A total of five questions measured employees' feeling about the organization and 25 questions measured employees' relationship with the organization. The measure has been validated (Reichheld, 2001) and the current study also confirmed its internal reliability (alpha $=0.95)$.

Work-family balance. This variable was measured by using five questions. These questions were taken from Helmle (2010) instrument. The internal consistency of the measure has been previously established (Helmle, 2010) and was also supported in the current study (alpha $=0.83$ ).

Perceived management concern for the employees. In order to measure this variable, five questions was taken from Shockley-Zalabak, Ellis, and Cesaria (2000) instrument and to increase the validity of the instrument the authors added three more questions for measuring perceived management concern for employees. The scale demonstrated high internal reliability (alpha $=0.90)$.

Work-role salience. Heinen (2005) instrument was taken to measure employees' work-role salience. Each of the work-role value and work-role commitment dimensions were measured by five questions. This scale also demonstrated high internal reliability in the current study (alpha $=0.80$ ).

\subsection{Data Analysis}

The Lisrel program was used to represent the result of the Structural Equation Modeling (SEM) of the research and the results compared with their standard fit indices. Absolute fit indices demonstrate which proposed model has the most superior fit. These measures provide the most fundamental indication of how well the proposed theory fits the data (Hooper et al., 2008). In this research four of the most popular fit indices were taken to evaluate the fitness of the model:

$\chi 2 / d f$ index: An acceptable ratio for this statistic ranges from as high as 5.0 (Wheaton et al, 1977) to as low as 2.0 (Tabachnick and Fidell, 2007).

Root Mean Square Error of Approximation (RMSEA): An RMSEA in the range of 0.05 to 0.10 was considered an indication of fair fit and values above 0.10 indicated poor fit (MacCallum et al, 1996 cited in Hooper et al., 2008).

Comparative fit index (CFI): values for this statistic range between 0.0 and 1.0 with values closer to 1.0 indicating good fit. A cut-off criterion of CFI $\geq 0.90$ was initially advanced (Hooper et al., 2008) however, recent studies have shown that a value greater than 0.90 is needed in order to ensure that misspecified models are not accepted (Hu and Bentler, 1999).

Normed-fit index (NFI): Values for this statistic range between 0 and 1 with Bentler and Bonnet (1980) recommending values greater than 0.90 indicating a good fit.

\section{Results}

To evaluate the model appropriateness for structural modeling we first tested the scales reliability and the correlations among the research variables. Reliability and correlations are displayed in Table 1. The results showed that all the variables have positive meaningful relationships with each other. The assumption that all the variables are 
measured without error, a necessary condition of observed path analysis (Kelloway, 1998), was also met in the current study, as demonstrated by the high reliabilities of the scales as a desired condition for structural modeling.

Table 1. Reliability and inter-correlations among variables

\begin{tabular}{llllll}
\hline & LTM & WFB & PMCE & WRS & OL \\
\hline LTM & - & $0.470^{* *}$ & $0.422^{* *}$ & $0.449^{* *}$ & $0.472^{* *}$ \\
WFB & - & - & $0.377^{* *}$ & $0.726^{* *}$ & $0.480^{* *}$ \\
PMCE & - & - & - & $0.460^{* *}$ & $0.758^{* *}$ \\
WRS & - & - & - & - & $0.620^{* *}$ \\
Alpha & $(0.98)$ & $(0.83)$ & $(0.90)$ & $(0.80)$ & $(0.95)$ \\
\hline
\end{tabular}

Notes: $p, 0.05 ; * p<0.01 ; * * p<0.001 ; n=248$; LTM - Leisure Time Management; WFB - Work Family Balance; PMCE - Perceived Management Concern for Employees; WRS - Work Role Salience; OL - Organizational Loyalty

The result of the Structural Equation Modeling (SEM) of the research is shown in the figure 4. The amounts of the effects between variables are based on the standard estimates.

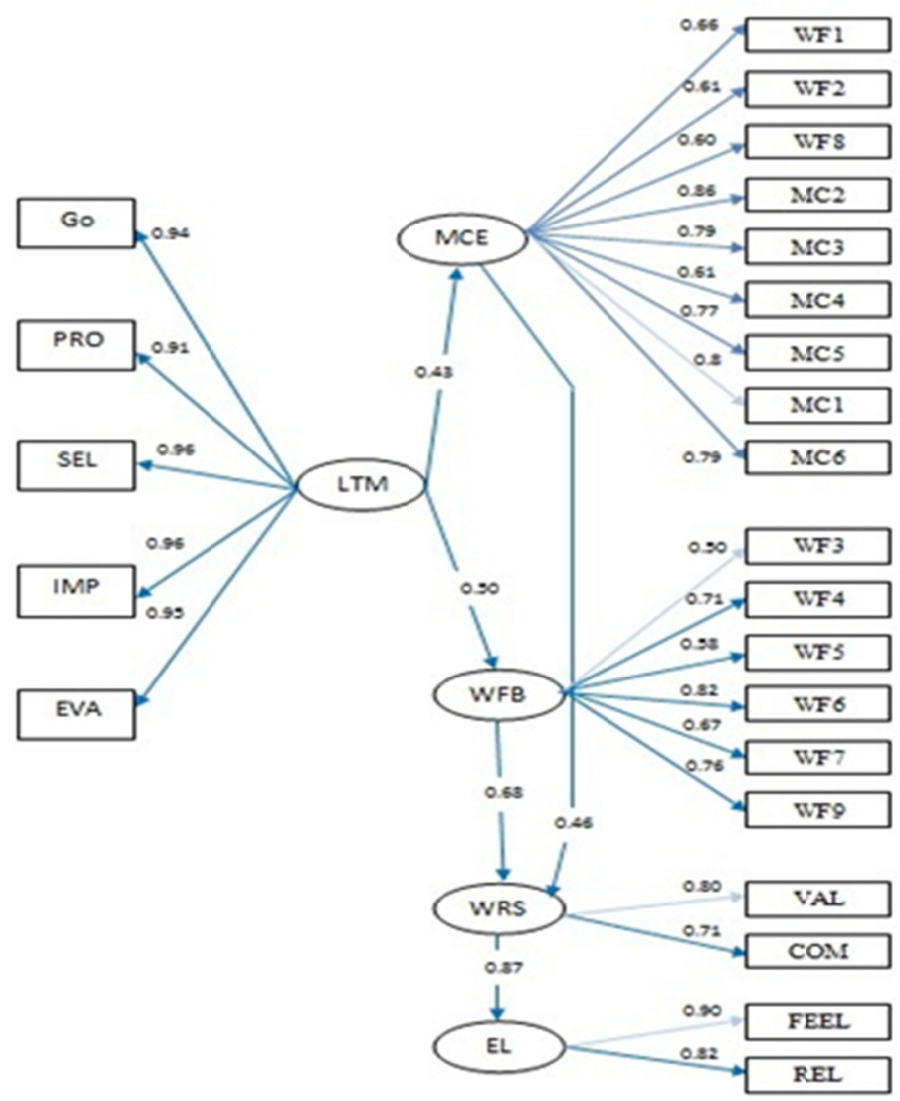

Chi-Square $=113.80, \quad \mathrm{DF}=47, \quad$ P-value $=0.00000, \quad$ RMSEA $=0.082, \quad$ CFI $=0.92, \quad \mathrm{NFI}=0.9$

Notes: $n=248$; All shown coefficient significant at $\mathrm{p}<0.001$; LTM - Leisure Time Management;

MCE-Management Concem for Employees; WFB - Work Family Balance; WRS - Work Role Salience; EL - Employee Loyalty

Figure 4. Standardized parameter estimates of the research model

Based on the figure above, the structure of the hypothetical model of the interactions between leisure time management, work-family balance, perceived management concern for employee, work-role salience and employee loyalty are supported by chi-square statistics (113.80). The RMSEA index should be lower than its significant level 
(0.1), which is (0.082) for this model and shows an acceptable fitness of the data in the model. The amount of chi-square/df index (2.42), CFI (0.92) and NFI (0.9) for this model are also consistent with their standard modes.

As indicated in the figure 4 leisure time management in organization has a positive meaningful effect on employees' work-family balance (confirmation of $\mathrm{H} 1$ ) and also has a positive meaningful effect on perceived management concern for employees (confirmation of H2). The result of the path analysis of the research model shows that both employees' work-family balance and perceived management concern for employees have positive meaningful effects on employees' work-role salience (confirmation of H3 and H4). Finally, employees' work-role salience has a positive meaningful effect on their organizational loyalty (confirmation of H5) and the overall structure of the research model is confirmed.

\section{Discussion}

The result of the first hypothesis indicated that as a new function of human resource management, leisure time management has a positive influence on employees' work-family balance. Leisure activities are designed and suggested to employees in order to help them in fulfilling their non-working times and improving their physical and psychological health, therefore such recreation programs can strengthen employees' abilities to adjust themselves with both their works and families responsibilities and make a balance between these two main parts of life. Also, most of the time within the organizations that consider leisure time management in their human resource management processes, there are some voluntary special leisure programs that are designed and suggested not only to employees, but also to their family members. In such situations, employees face with opportunities to attend in their organization's voluntary recreation programs with their families members, for example with their partners or children. Such leisure programs can improve families' attitudes about the organization of their working partners or parents. Therefore, families' positive attitudes and images about their partner/parent organization can be helpful to persuade them to understands and adapt themselves with their partner/parents work conditions and their probable work pressures. According to the result of the current study in such situations employees will face with lower levels of conflict between their works and families demands.

The second result of the study showed that within the organizational context, leisure time management has a positive influence on perceived management concern for employees. Despite of the critical role of leisure time management on employees wellbeing, there are few organizations that are committed to provision voluntary, leisure program through their human resource management processes. Based on the result of the current study, if employees desire to accept voluntary recreation programs provided by their working organizations in order to help them to be engaged in interesting activities during their non-working times, they will have better perception of their managers and accept that managers not only think about work but also consider employees wellbeing and their personal needs.

The third result of the study explored the positive effect of work-family balance on employees' work-role salience. The quality of the relationship between work and family and the necessity of making balance between work and family responsibilities have been two of the concerns for employees and most of the time these concerns has strong effects on employees' performance both in their works and families. Based on the result of the current study, from the employees' points of view one of the important factors that can determine the value of a job and also has influence on the level of employees' commitment to their job in an organization is related to the capacity of their working organization to provide situations for employees to make balance between their jobs and families responsibilities. Therefore, if employees can make balance between their works and families situations, with a special help from their working organization, they will have much more work-role salience during their working times.

The forth result of the study indicated the positive influence of perceived management concern for employees on their work-role salience. On the basis of this finding, if employees perceive that within their organization all the managerial decisions and practices are consistent with their needs and interests, they will experience a favorable attitude toward their work and will have a high level of work value and commitment. Since employee-friendly behaviors is one of the important factors that employees consider to evaluate their managers practices, within the organizational context employees' work values and commitment are determined by evaluating managerial behaviors. Therefore in an organization work-role salience will occurs when employees evaluate managerial behaviors consistent with their personal needs and interests.

The final result of the current study implied that employees' work-role salience has a positive influence on their organizational loyalty. On the basis of this finding work role salience appears for employees when they feel strong positive feelings toward their work contents. According to Amarea (1986) employees who perceived their jobs as salient, are those who place high values on their work contents and are committed to devote their ability to do their 
jobs well. Such psychological feelings toward the job activities in an organization promote employees' motivation to do their work responsibilities with honor and also increase their desire to continue their relationship with the working organization for a long period of time. In other words, if employees love their works they place high levels of value on their working activities and are committed to their works' contents. Such feelings toward the occupied work promote employees' loyalty to their organization because this work is a part of its overall structure and processes.

\subsection{Conclusion and Recommendations}

This research provides a number of contributions to the theoretical debate about leisure time management, work-family balance, perceived management concern for employees, work-role salience and employees' loyalty.

The first contribution is that this study explored the effect of leisure time management on employees' loyalty with the consideration of work-family balance, perceived management concern for employees and work-role salience as significant mediators. Moreover, to test the conceptual model, this study introduced a new model of leisure time management to its relevant literature and also for other research variables it relied on valid models from the literature.

The second contribution refers to this fact that leisure time management as an important organizational practice leads to suitable personal and organizational outcomes such as work-family balance, perceived management concern for employees and with the direct effect of these two variable on work-role salience, it will lead to the increase of employees' loyalty.

Finally the result of the current study tried to make organizational decision makers and human resource managers pay much more attentions to effective leisure time management in their organizational endeavors.

\subsection{Limitations and Direction for Future Research}

This particular research study has a number of limitations that we wish to address. Our study was centered in a public sector organization operating within the Iranian Oil industry. Additional research is necessary to determine whether the relationships identified can be generalized to other types of organizations, for example private organizations. Second, the study was conducted within a single cultural context. The effects of variables were examined in a single country with a fairly homogeneous group of individuals in term of national culture. Therefore, further empirical research is suggested to be enhanced in different cultural contexts, for example in international organizations or different countries, to determine the effect of national culture in organizational studies.

To conclude, this research has solely examined the effect of employees' leisure time management on their organizational loyalty with the consideration to the role of work-family balance, perceived management concern for employees and work-role salience as significant mediators. Future research should aim to theoretically and empirically explore the effect of leisure time management on other key variables such as psychological empowerment, organizational performance and turnover intent, especially in a multi-cultural context.

\section{References}

Allen, T.D. (2001). Family-Supportive Work Environments: The Role of Organizational Perceptions. Journal of Vocational Behavior, 58, 414-35. http://dx.doi.org/10.1006/jvbe.2000.1774

Arai, Kazuhiro. (1995). Organizational loyalty: A preliminary Study. Hitotsubashi Journal of Economics, 36, 21-32.

Ashforth, B.E., Kreiner, G.E., \& Fugate, M. (2000). All in a day's work: boundaries and micro role transitions. Academy of Management Review, 25(3), 472-91.

Baral, Rupashree, \& Bhargava, Shivganesh. (2010). Work-Family Enrichment as a Mediator Between Organizational Interventions for Work-Life Balance and Job Outcomes. Journal of Managerial Psychology, 25(3), 274-300. http://dx.doi.org/10.1108/02683941011023749

Barnett, R.C. (1998). Toward a review and reconceptualization of the work/family literature. Genetic, Social, and General Psychology Monographs, 124, 125-82.

Beham, Barbara, \& Drobnic, Sonja. (2010). Satisfaction with work-family balance among German office workers. Journal of Managerial Psychology, 25(6), 669-89. http://dx.doi.org/10.1108/02683941011056987

Bentler, P.M., \& Bonnet, D.C. (1980). Significance Tests and Goodness of Fit in the Analysis of Covariance Structures. Psychological Bulletin, 88(3), 588-606. http://dx.doi.org/10.1037/0033-2909.88.3.588 
Bettencourt, Lance A., Gwinner, Kevin P., \& Meuter, Matthew L. (2001). A Comparison of Attitude, Personality and Knowledge Predictors of Service-Oriented Organizational Citizenship Behaviors. Journal of applied Psychology, 86(1), 29-41. http://dx.doi.org/10.1037/0021-9010.86.1.29

Blanchard, Ce'line M., Tremblay, Maxime A., Mask, Lisa and Perras, \& Me'lanie G.M. (2009). A combination of work environment factors an individual difference variable in work interfering with family. International Journal of Workplace Health Management, 2(1), 63-90. http://dx.doi.org/10.1108/17538350910946018

Borucki, Chester C., \& Michael J. Burke. (1999). An Examination of Service-Related Antecedents to Retail Store Performance. Journal of Organizational Behavior, 20(6), 943-62. http://dx.doi.org/10.1002/(SICI)1099-1379(199911)20:6<943::AID-JOB976>3.0.CO;2-9

Briazgounov, I. P. (1988). The role of physical activity in the prevention and treatment of noncommunicable diseases. World Health Statistics Quarterly, 41, 242-50.

Brown, G. W., Bifulco, A., \& Harris, T. O. (1987). Life events, vulnerability and onset of depression. British Journal of Psychiatry, 150, 30-42. http://dx.doi.org/10.1192/bjp.150.1.30

Burke, Michael J., Chester C. Borucki, \& Amy E. Hurley. (1992). Re-conceptualizing Psychological Climate in a Retail Service. Journal of Applied Psychology, 77(5), 717-29. http://dx.doi.org/10.1037/0021-9010.77.5.717

Burke, Ronald J. (2010). Correlates of work-family conflicts among managers in Egypt. International Journal of Islamic and Middle Eastern Finance and Management, 3(2), 113-31. http://dx.doi.org/10.1108/17538391011054363

Burton, A. (1994). The rise and fall of British shipbuilding. London: Constable.

Campbell, A. B. (1979). The Lanarkshire miners - A social history. Edinburgh: J Donald Publishers.

Carlson, D. S., Kacmar, K. M., \& Williams, L. J. (2000). Construction and initial validation of a multidimensional measure of work-family conflict. Journal of Vocational Behavior, 56, 249-76. http://dx.doi.org/10.1006/jvbe.1999.1713

Caudroit, Johan, Boiche', Julie, Stephan, Yannick, Le Scanff, Christine, \& Trouilloud, David. (2011). Predictors of work/family interference and leisure-time physical activity among teachers: The role of passion towards work. European Journal of Work and Organizational Psychology, 1-19. Retrieved from http://www.psypress.com/ejwop

Chen, Z. X., Tsui, A. S., \& Farh, J. (2002). Loyalty to supervisor vs. organizational commitment: Relationship to employee performance in China. Journal of Occupational and Organizational Psychology, 75(3), 339. http://dx.doi.org/10.1348/096317902320369749

Chu, Cordia, Breucker, Gregor, Harris, Neil, Stitzel, Andrea, Gan, Xingfa, Gu, Xueqi, \& Dwyer, Sophie. (2000). Health-promoting workplaces - international settings development. Health Promotion International, 15(2), 155-67. http://dx.doi.org/10.1093/heapro/15.2.155

Clark, S.C. (2000). Work/family border theory: a new theory o work/family balance. Human Relations, 53(6), 747-70. http://dx.doi.org/10.1177/0018726700536001

Cotte, J. (1976). Perceiving time: A Psychological Investigation With Men and Women. John Wiley and Sons, New York, NY.

Cotte, Jones, \& Ratneshwar, S. (2003). Choosing leisure Services: The Effects of Consumer Time style. Journal of Service marketing, 17(6), 558-72. http://dx.doi.org/10.1108/08876040310495609

Coughlan, R. (2005). Employee loyalty as adherence to shared moral values. Journal of Managerial Issues, 17(1), 43.

Dunseath, J., Beehr, T.A., \&King, D.W. (1995). Job stress-social support buffering effects across gender, education and occupational group in municipal workforce. Review of Public Personnel Administration, 15, 60-83. http://dx.doi.org/10.1177/0734371X9501500105

Eby, L.T., Casper, W.J., Lockwood, A., Bordeaux, C., \& Brinley, A. (2005). Work and Family Research in IO/OB: Content Analysis and Review of the Literature (1980-2002). Journal of Vocational Behavior, 66, 124-97. http://dx.doi.org/10.1016/j.jvb.2003.11.003

Eisenberger, R., Huntington, R., Hutchison, S., \& Sowa. D. (1986). Perceived Organizational Support. Journal of Applied Psychology, 71, 500-7. http://dx.doi.org/10.1037/0021-9010.71.3.500 
Eisenberger, R., Fasolo, P., \& Davis-Lamastro, V. (1990). Perceived organizational support and employee diligence, commitment, and innovation. Journal of Applied Psychology, 75, 51-59. http://dx.doi.org/10.1037/0021-9010.75.1.51

Erdly, Marvin, \& Kesterson-Townes, Lynn. (2004). Experience Rule: A Scenario for the Hospitality and leisure in Industry Circa 2010 Envision Transformation. Strategy and Leadership, 31(3), 12-18. http://dx.doi.org/10.1108/10878570310698250

Faleye, Olubunmi, \& Trahan, Emery. (2007). Is What's Best for Employees Best for Shareholders? College of Business Administration Northeastern University Boston, MA 02115-5000.

Faleye, Olubunmi, \& Trahan, Emery. (2010). Labor-friendly Corporate Practices: Is What is Good for Employees Good for Shareholders? College of Business Administration Northeastern University, Boston, MA 02115.

Foley, Malcolm, \& McGillivray, David. (2000). Absence from or absence of work in the 'leisure industries': free-time or displacement? Managing Leisure, 5, 163-80. http://dx.doi.org/10.1080/13606710010001761

Foley, Mal colm, Max well, Gill, \& David McGil livray. (1999). Women at Leisure and in Work -Unequal Opportunities? Equal Opportunities International, 18(1), 8-18.

Frone, M. R., Russell, M., \& Cooper, M. L. (1992). Antecedents and outcomes of work-family conflict: testing a model of the work-family interface. Journal of Applied Psychology, 77(1), 65-75. http://dx.doi.org/10.1037/0021-9010.77.1.65

Frone, M. R., Russell, M., \& Cooper, M. L. (1995). Job stressors, job involvement and employee health: A test of identity theory. Journal of Occupational and Organizational Psychology, 68, 1-11. http://dx.doi.org/10.1111/j.2044-8325.1995.tb00684.x

Godbey, Geoffrey. (2000). The Future of Leisure Studies. Journal of Leisure Research, 32(1), 37-41.

Greenhaus, J.H. (1971). An investigation of the role of career salience in vocational behavior. Journal of Vocational Behaviour, 1, 209-16. http://dx.doi.org/10.1016/0001-8791(71)90022-4

Greenhaus, J.H. (1973). A factorial investigation of career salience. Journal of Vocational Behaviour, 3, 95-98. http://dx.doi.org/10.1016/0001-8791(73)90050-X

Gutek, B.A., Repetti, R.L., \& Silver, D.L. (1988). Nonwork roles and stress at work. In Cooper, C.L. and Payne, R. (Eds.), Causes, Coping, and Consequences of Stress at Work. Wiley, New York, NY.

Hall, E. T. (1976). The Hidden Dimension. Anchor-Press Doubleday, New York, NY.

Heinen, Beth A. (2009). Leadership's Influence on Nonwork Outcomes: The Mediating Role of Work-Family Climate. A dissertation submitted in partial fulfillment of the requirements for the degree of Doctor of Philosophy at George Mason University.

Helmle, Jill Robin. (2011). Copreneurs and Communication: Work-Family Balance in Married Couples' Family Businesses. A Dissertation submitted in partial satisfaction of the requirements for the degree Doctor of Philosophy in Communication, University of California.

Higgins, C.A., Duxbury, L.E., \& Irving, R.H. (1992). Work-family conflict in dual-career Family. Organizational Behavior and Human Decision Processes, 51(1), 51-75. http://dx.doi.org/10.1016/0749-5978(92)90004-Q

Hoffmann, \& Elizabeth A. (2006). Exit and Voice: Organizational Loyalty and Dispute Resolution Strategies. Social Forces, 84(4), 2313-30. http://dx.doi.org/10.1353/sof.2006.0093

Holbrook, M.B. (1993). Nostalgia and Consumption Preferences: Some Emerging Patterns of Consumer Tastes. Journal of consumer Research, 20, 245-56. http://dx.doi.org/10.1086/209346

Holliday, R., \& Thompson, G. (2001). A body of work. In R. Holliday and J. Hassard (Eds.), Contested bodies (pp.117-134). London: Routledge.

Holman, R.H. (1981). The imagination of the Future: A Hidden Conception in the Study of Consumer Decision making. In Monroe, K.B. (Ed.), Advances in Consumer Research (Vol. 8, pp. 187-91). Association for Consumer Research, Ann Arbor, MI.

Hooper, Daire, Coughlan, Joseph, and Mullen, \& Michael R. (2008). Structural Equation Modelling: Guidelines for Determining Model Fit. Electronic Journal of Business Research Methods, 6(1), 53-60. 
Hu, L.T., \& Bentler, P.M. (1999). Cutoff Criteria for Fit Indexes in Covariance Structure Analysis: Conventional Criteria Versus New Alternatives. Structural Equation Modeling, 6(1), 1-55. http://dx.doi.org/10.1080/10705519909540118

Jones, J.M. (1988). Cultural Differences in Temporal Perspectives. In Mcgrath, J.E. (Ed.), The Social Psychology of Time: New perspectives (pp. 21-38). Sage, Newbury Park, Ca.

Kaufman, C.F., Lane, P.M., \& Lindquist, J.D. (1991). Exploring More Than 24 Hours a Day: A preliminary Investigation of polychromic Time se. Journal of Consumer Research, 18, 392-401. http://dx.doi.org/10.1086/209268

Kelloway, E.K. (1998). Using LISREL for Structural Equation Modeling. Sage, Thousand Oaks, CA.

Luo Lu, Kao, Shu-Fang, Cooper, Cary L., Allen, Tammy D., Lapierre, Laurent M., O’Driscoll, Michael, ...Spector, Paul E. (2009). Work Resources, Work-to-Family Conflict, and Its Consequences: A Taiwanese-British Cross-Cultural Comparison. International Journal of Stress Management, 16(1), 25-44. http://dx.doi.org/10.1037/a0013988

Manrai, L.A., \& Manrai, A.K. (1995). Effects of Cultural-Context, gender and acculturation on Perceptions of Work Versus Social/Leisure Time Usage. Journal of Business Research, 32, 115-28. http://dx.doi.org/10.1016/0148-2963(94)00034-C

Marcinkus, Wendy C., Whelan-Berry, Karen S., \& Gordon, Judith R. (2007). The Relationship of Social Support to the Work-Family Balance and Work Outcomes of Midlife Women. Women in Management Review, 22(2), 86-111. http://dx.doi.org/10.1108/09649420710732060

Martensen, Anne, \& Grønholdt, Lars. (2006). Internal Marketing: A Study of employee Loyalty, Its Determinants and Consequences. Innovative Marketing, 2(4), 92-116.

Martire, L. M., Stephens, M. A. P., \& Townsend, A. L. (2000). Centrality of women's multiple roles: Beneficial and detrimental consequences for psychological well-being. Psychology and Aging, 15, 148-56. http://dx.doi.org/10.1037/0882-7974.15.1.148

Merton, R. K. (1957). Social theory and social structure. Glencoe, IL: Free Press.

Meyer, John P., \& Natalie J. Allen. (1997). Commitment in the Workplace: Theory, Research, and Application. Sage Publications.

Moore, Fiona. (2007). Work-Life Balance: Contrasting Managers and Workers in an MNC. Employee Relations, 29(4), 385-99. http://dx.doi.org/10.1108/01425450710759217

Noor, Noraini M. (2004). Work-Family Conflict, Work- and Family-Role Salience, and Women's Well-Being. The Journal of Social Psychology, 144(4), 389-405. http://dx.doi.org/10.3200/SOCP.144.4.389-406

Parks, K. M., \& Steelman, L. A. (2008). Organizational wellness program: A meta-analysis. Journal of Occupational Health Psychology, 13, 58-68. http://dx.doi.org/10.1037/1076-8998.13.1.58

Peloso, Antony Frederick. (2004). The Antecedents of the Employee Loyalty-Customer Loyalty Relationship. School of Advertising Marketing and Public relations, Queensland University of Technology.

Philipp, S.F. (1992). Time orientation and Participation in Leisure Activities. Personal and Motor skills, 75, 659-64. http://dx.doi.org/10.2466/pms.1992.75.2.659

Pisarik, Christopher T. (2006). The Relationship Among Work Possible Selves, Work-role salience, Socioeconomic Position, And The Psychological Well-Being Of Individuals In Early Adulthood. A Dissertation Submitted to the Faculty of The Graduate School at The University of North Carolina at Greensboro.

Pitchford, Andy, \& Bacon, William. (2005). Constructing knowledge: the case of leisure management in the UK. Studies in Higher Education, 30(3), 311-26. http://dx.doi.org/10.1080/03075070500095747

Powell, Gary N., \& Greenhaus, Jeffrey H. (2006). THINK PIECE Is the opposite of positive negative? Career Development International, 11(7), 650-59. http://dx.doi.org/10.1108/13620430610713508

Reichheld, Frederick F. (2001). Loyalty Rules!: How Today's Leaders Build Lasting Relationship. Harvard Business School Publishing. 
Reitzes, D. C., \& Mutran, E. J. (1994). Multiple roles and identities: Factors influencing self-esteem among middle-aged working men and women. Social Psychology Quarterly, 57, 313-25. http://dx.doi.org/10.2307/2787158

Rhee, U., Uleman, J.C., Lee, H.K., \& Roman, R.J. (1995). Spontaneous Self-Descriptions and Ethnic Identities in Individualistic and Collectivistic Cultures. Journal of Personality and social psychology, 69(1), 142-52. http://dx.doi.org/10.1037/0022-3514.69.1.142

Sanz-Vergel, Ana Isabel, Demerouti, Evangelia, Bakker, Arnold B., \& Moreno-Jiménez, Bernardo. (2011). Daily detachment from work and home: The moderating effect of role salience. Human relations, 1-25. http://dx.doi.org/10.1177/0018726710393368

Savinainen, M., Arolab, H., Nygard, C.-H., Siukola, A., Luukkaala, T., Virtanen, P., \& Taskinen, H. (2005). Total work and leisure-time load in relation to sickness absences in the food industry. International Congress Series 1280, 224-27. http://dx.doi.org/10.1016/j.ics.2005.02.063

Shockley-Zalabak, P., Ellis, K., \& Cesaria, R. (2000). Measuring organizational trust: Cross-cultural survey and index. San Francisco: IABC Research Foundation.

Tabachnick, B.G., \& Fidell, L.S. (2007). Using Multivariate Statistics (5th ed.). New York: Allyn and Bacon.

Thøgersen-Ntoumani, C., Fox, K. R., \& Ntoumanis, N. (2005). Relationships between exercise and three components of mental well-being in corporate employees. Psychology of Sport and Exercise, 6, 609-27. http://dx.doi.org/10.1016/j.psychsport.2004.12.004

Thoits, P. A. (1995). Identity-relevant events and psychological symptoms: A cautionary tale. Journal of Health and Social Behavior, 36, 72-82. http://dx.doi.org/10.2307/2137288

Thompson, C.A., Jahn, E.W., Kopelman, R.E., \& Prottas, D.J. (2004). Perceived organizational family support: a longitudinal and multilevel analysis. Journal of Managerial Issues, 16, 545-65.

Touve, David, \& Tepper, Steven. (2007). Leisure in America: Searching for the forest amongst the trees. $A$ convening hosted by National Arts Strategies and the Getty Leadership Institute, May 10-11.

Turner, Michelle, Lingard, Helen, \& Francis, Valerie. (2009). Work-Life Balance: An Exploratory Study of Supports and Barriers in a Construction Project. International Journal of Managing Projects in Business, 2(1), 94-111. http://dx.doi.org/10.1108/17538370910930536

Warren, J. A., \& Johnson, P. J. (1995). The impact of workplace support on work-family role strain. Family Relations, 44, 163-69. http://dx.doi.org/10.2307/584803

Wheaton, B., Muthen, B., Alwin, D., F., \& Summers, G. (1977). Assessing Reliability and Stability in Panel Models. Sociological Methodology, 8(1), 84-136. http://dx.doi.org/10.2307/270754

Whitener, E. M. (2001). Do "high commitment" Human Resource Practices Affect Employee Commitment? A Cross-level Analysis Using Hierarchical Linear Modeling. Journal of Management, 27, 515-35. 